\title{
Monopol på Ligestilling? \\ Etniske minoritetskvinder om 'dansk' ligestilling
}

Af Helene Pristed Nielsen

Ev der ligestilling i Danmark? Ligestillingsdebatten $i$ Danmark er ofte monopoliserende, men debatten kan nuanceres betragteligt ved at invitere nye debattorer $i$ form af kvinder med etnisk minoritetsbaggrund med ind.

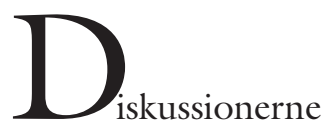

af ligestilling som normativt ideal og som empirisk fænomen i Danmark har lange forhistorier. Denne artikel inddrager interviews med en række forkvinder og ledende medlemmer af etniske minoritetskvindeforeninger ${ }^{1}$ rundt om i Danmark i diskussionen. Dette bidrager til at nuancere billedet af ligestilling som empirisk fænomen i Danmark, fordi disse kvinder i den offentlige debat ofte markeres som udenforstående til en dansk ligestillingspraksis, samtidig med at de faktisk ofte har stærke meninger om og erfaringer med ligestillingsspørgsmål. Inddragelsen af deres syn på ligestilling bidrager samtidig til at accentuere en teoretisk skelnen mellem mulighedslighed og udfaldslighed, samt at understrege hvor polariseret ligestillingsdebatten er. ${ }^{2}$

Teoretisk skelnes der mellem mulighedslighed og udfaldslighed. Førstnævnte handler om hvorvidt mennesker har lige muligheder, sidstnævnte om fordelingen af goder efter at folk har forvaltet deres muligheder 
(Holtug og Lippert-Rasmussen 2009: 9). Mulighedslighed er dog langt fra et simpelt politisk ideal, fx kan det diskuteres hvilken rolle personlige kvalifikationer og ansvar for egne valg skal tillægges (se Holtug og Lippert-Rasmussen 2009: 21-44). Desuden er det væsentligt at skelne mellem en rent juridisk sikring mod kønsdiskrimination og en bredere opfattelse af mulighedslighed, der fx involverer fravær af sexistiske normer (Borchorst 2009: 186).

Artiklens omdrejningspunkt er de syn på ligestilling jeg har mødt blandt etniske minoritetskvinder bosiddende i Danmark. Der er tale om en heterogen gruppe af kvinder, der enten selv er flygtet eller indvandret til Danmark fra overvejende muslimske lande, eller har forældre for hvem dette gælder. Materialet vil blive yderligere præsenteret nedenfor, men som udgangspunkt er det vigtigt at understrege en forventelig diversitet $\mathrm{i}$ ligestillingsopfattelserne blandt disse kvinder - og at de derved næppe adskiller sig fra majoritetsbefolkningen. ${ }^{3}$

Det er væsentligt at lytte særskilt til disse kvinders syn på ligestilling, både fordi "forskellige etniske minoriteters oplevelse af og syn på kønsligestilling, og hvordan de lever med og tænker ligestilling" er et underbelyst empirisk spørgsmål (Seidenfaden et al. 2011: 14). Men også fordi en herskende problemopfattelse i den danske debat er at denne gruppe af kvinder mangler ligestilling, og at grunden til denne mangel skal findes hos dem selv og deres familier (Borchorst 2009: 173). Jeg fremstiller derfor kvindernes syn på og oplevelser med ligestilling, fordi jeg mener det kan nuancere debatten og give stemmer til centrale, men paradoksalt sjeldent hørte, aktører i debatten.

I den forstand etnificerer eller racialiserer jeg kvinderne ved at kategorisere dem som en gruppe der kan bibringe debatten noget nyt. Skønt jeg deler Linda Alcoffs bekymring over at "tale for andre" (1991-92), vil jeg fremhæve at en forudsætning for at "cOunter sentences" (Spivak 1988) - dvs. alternativer til den forelagte fremstilling - kan opstå, er at man i første omgang overhovedet taler til 'den Anden'. Dermed tilslutter jeg mig Sherin Khankans opfattelse af at en ikke-monopoliserende dialog om ligestilling er ønskelig (2006: 154). I en diskussion af lighedsopfattelser i Norge, siger Gullestad at "by linking the voices of people who can be expected to argue with each other, doxic fields of underlying values and perceptions can be identified" (2002: 58). Analogt til Gullestads ræsonnement er det min påstand, at ved at sætte dominerende forestillinger om 'dansk' ligestilling i dialog med synspunkter fra personer der på forhånd er diskursivt markeret som "problembærere" (Bacchi 2009) åbnes en dør for potentielle 'counter sentences'.

\section{LIGESTILLING: ET DANSK VAREMÆRKE?}

Hvis man studerer såvel den internationale som den nationale debat om ligestilling $\mathrm{i}$ Danmark, kunne man foranlediges til at tro at ligestilling på det nærmeste er et dansk varemærke. Således placerer World Economic Forum (WEF) i den seneste Global Gender Gap Report Danmark som nummer 7 på en rangliste over 135 lande (WEF 2011: 8-9). En placering Danmark har bibeholdt siden 2008. Også OECD producerer data om forskelle mellem kønnene (OECD 2011). Heraf fremgår det bl.a., at Danmark ligger helt i top blandt OECD-lande hvad angår mulighederne for at få passet børn under tre år udenfor hjemmet.

Når man sammenstiller de forskellige informationer fra WEF og OECD, er det tydeligt at de måler ligestilling på forskellig vis. Rapporten fra WEF præciserer at de ønsker at måle "gaps in outcome variables rather than gaps in means or input variables" (WEF 2011: 3), altså udfaldslighed fremfor mulighedslighed. Dette begrundes yderligere:

The Index is designed to measure genderbased gaps in access to resources and opportunities in individual countries rather than the 
actual levels of the available resources and opportunities in those countries. [...] the Index is constructed to rank countries on their gender gaps not on their development level (WEF 2011: 3).

Når OECD derimod angiver muligheden for at få passet små børn udenfor hjemmet, er der ingen kausal relation mellem dette forhold og udfaldslighed. Noget man kan forsikre sig om ved at studere tabellerne over andelen af kvindelige bestyrelsesmedlemmer eller størrelsen på løngabet, der tydeligt indikerer at ligestilling $\mathrm{i}$ form af udfaldslighed ikke sikres alene ved mulighedslighed. ${ }^{4}$ Men uanset om udgangspunktet er mulighedslighed eller udfaldslighed, placerer disse internationale organisationer Danmark højt på deres ranglister over lande med ligestilling.

Samtidig med den internationale anerkendelse af Danmarks høje placering vedrørende ligestilling, har bl.a. den tidligere Venstre/Konservative regering i perioden 2001-2011 ofte fremhævet Danmark som et land med ligestilling (Andreassen og Siim 2007), skønt denne diskurs ikke har været afgrænset til medlemmer af netop disse partier. På baggrund af interviews med politikere på begge fløje i Folketinget, påviser Rolandsen Agustín (2009), at der er divergerende opfattelser af hvad ligestillingsnormen indbefatter. Således identificerer hun et fokus på arbejdsmarkedsdeltagelse som en vej til ligestilling blandt indvandrere $\mathrm{i}$ interviews med medlemmer af Venstre og Dansk Folkeparti, mens de interviewede socialdemokrater også ser arbejdsmarkedet som et vigtigt ligestillingsfelt, men fremhæver problemer med kønssegregering og uligeløn. De interviewede SF'ere fremhæver derimod ligestilling som en rettighed der kræver mobilisering i civilsamfundsorganisationer. Samlet set konkluderer Rolandsen Agustín, at der eksisterer en stærk diskurs på tværs af politiske partier om Danmark som et ligestillet land højt placeret i forhold til de øvrige europæiske lande.
Parallelt med dette har en række forskere peget på hvorledes ligestillingsdebatten i Danmark mellem 2001-2011 ofte kom til at handle om indvandrerkvinders manglende ligestilling (bl.a. Borchorst 2009). Den diskursive markering af etniske danskere som ligestillede, mens indvandrere fremstilles som ikke-ligestillede, finder måske sit skarpeste officielle udtryk i den også nugældende 'Erklæring om integration og aktivt medborgerskab i det danske samfund', hvori ansøgere om dansk statsborgerskab bl.a. skal skrive under på følgende:

- Jeg anerkender, at mænd og kvinder har lige pligter og rettigheder i Danmark [...].

- Jeg anerkender, at der i Danmark skal være lige respekt og udfoldelsesmuligheder for alle børn - både piger og drenge - så de kan vokse op til at blive aktive og ansvarlige medborgere, der er i stand til at træffe deres egne valg $[\ldots]$.

- Jeg respekterer det enkelte menneskes frihed og personlige integritet, kønnenes ligestilling og tros- og ytringsfriheden, som er grundlæggende i Danmark (Udlændingestyrelsen 2006).

Der eksisterer altså en stærk, politisk sanktioneret, offentlig diskurs i Danmark om ligestilling som en dansk værdi, endog om ligestilling som et særligt dansk varemærke og dermed noget vi skal lære 'de andre'. Underforstået i denne diskurs ligger en præmis om, at andre (ikke-vestlige) kulturer $\mathrm{i}$ al almindelighed, og islam i særdeleshed, er uforenelige med ligestilling, og i visse tilfælde at islam er direkte kvindeundertrykkende (Andreassen 2007).

\section{'DE ANDRE' MED EN AKTIE I LIGESTILLINGSDEBATTEN}

Materialet består af interviews med 34 ledende medlemmer af etniske minoritetskvindeforeninger i hhv. København, Aarhus og Aalborg. Med udgangspunkt i en semistruktureret interviewguide, spurgte jeg ind 
til bevæggrunde for og erfaringer med at organisere kvinder i lokale foreninger. Foreningerne blev udvalgt på baggrund af deres navne, som ofte inkluderede ordet 'kvindeforening' eller andre indikationer af henvendelse (primært) til kvinder. ${ }^{5}$ Et andet kriterium var at der enten indgik et navn på et overvejende muslimsk oprindelsesland6 (fx Den Afghanske Kvindeforening), eller at navnet specifikt indikerede en tværetnisk organisering (fx Multikulturel Kvindeklub Amager). Grunden til at fokusere specifikt på foreninger med kvindelige medlemmer der enten var troende muslimer eller havde oprindelse i et land hvor islam er en dominerende religion, var diskursens identifikation af netop denne gruppe af kvinder som 'problembærerne'.

Der har i Danmark været en del mediedebat om islam og ligestilling, ikke mindst i forbindelse med Asmaa Abdol-Hamids kandidatur til Folketinget i 2007 (for analyser, se Jørgensen 2012; Andreassen 2007). I enkelte af disse debatter har det været fremhævet at islam og ligestilling ikke har et iboende modsætningsforhold (Khankan 2006), men dette synspunkt har ikke været dominerende. Der findes dog en del international litteratur, der ligesom Khankan fremhæver at feminisme og islam ikke er modsætninger (bl.a. Ahmed 1992; Badran 1994; Ali 2000), hvilket flere af mine respondenter også fremhæver.

Foreningerne blev fundet via internetsøgninger, bl.a. i kommunale lister over samarbejdspartnere, samt Kvinderådets netværksforeninger. Samtidig konsulterede jeg lister over bevilling af ' $\$ 18$ ' eller ' $\$ 115$ støtte' i de udvalgte kommuner.7 I perioden august 2007 til januar 2008 gennemførte jeg 24 formelle interviews med 34 forkvinder eller bestyrelsesmedlemmer i etniske minoritetskvindeforeninger. ${ }^{8}$ Kvinderne var tilsammen aktive i 26 forskellige foreninger, hvoraf 13 var tværetniske, 4 somaliske, 3 kurdiske, 2 palæstinensiske, 2 iranske, 1 tyrkisk og 1 afghansk. ${ }^{9}$

På baggrund af mit fokus på de fore- ningsaktive bestyrelsesmedlemmer er det klart, at synspunkter og oplevelser gengivet nedenfor ikke er repræsentative for den kvindelige indvandrerbefolkning som sådan. Respondenterne udgør langt fra en homogen gruppe. Bl.a. er der en spredning i deres uddannelsesprofil, fx har én en ph.d.-grad opnået inden ankomsten til Danmark, mens andre er uden uddannelse fra oprindelseslandet, og samtidig er der både selvstændige, privat og offentligt ansatte, samt modtagere af forskellige former for overførselsindkomster blandt dem. Aldersmæssigt er der en spredning fra 16 år til omkring 60 år, og mens hovedparten er ankommet som flygtninge eller via familiesammenføringer, er 14 af respondenterne født og opvokset i Danmark. I den forstand er gruppen lige så heterogen som den danske kvindelige befolkning $\mathrm{i}$ al almindelighed, og forventningen var da også at de ville udtrykke forskellige syn på ligestilling.

\section{ETNISKE MINORITETSKVINDER OM \\ 'DANSK' LIGESTILLING: ET OPGØR MED MONOPOLET?}

Et centralt spørgsmål i interviewene gik på hvorfor man havde valgt at danne en forening specifikt henvendt til kvinder, og som opfølgende spørgsmål spurgte jeg ind til opfattelser af ligestilling. Undtagen i to tilfælde. Disse to undtagelser er udtryk for metodisk inkonsekvens, og dog er de værd at dvæle ved. Begge interviews er karakteriseret ved tilbageholdenhed fra respondenterne; interviewudskrifter afslører mange tøvende svar og uafsluttede sætninger. Begge interviews foregik i frokoststuer på respondenternes arbejdspladser, hvilket gjorde at der indimellem var personer i lokalet med professionelle relationer til respondenten. I situationen har jeg tilsyneladende vurderet, at ligestilling var et upassende emne at diskutere. Her spiller min egen position som etnisk dansk majoritetskvinde utvivlsomt en rolle for interviewenes forløb, ${ }^{10}$ bl.a. besværliggør den dominerende 
diskurs mit ønske om at stille spørgsmålet som åbent, uden automatisk at sætte min respondent i rollen som 'problembærer'. Hvilket siger mere om diskursens dominans end dens relevans, og understreger at uden dialog er der ingen forhandling af dominerende forestillinger.

Mangfoldigheden blandt de 22 svar på mine spørgsmål om ligestilling understreger dog muligheden for dialog. Et mindretal (men dog et betydeligt mindretal) på seks personer, tilkendegav at ligestilling var et svært emne, som kunne lede til konflikter enten i deres foreningskontekst eller i al almindelighed. Enkelte ønskede ganske enkelt at undgå emnet: “jeg synes vi har sat en grænse for det. [...] vi synes ikke det kunne bære det. Det var for svært. Måske mister vi lige pludselig alle sammen på én gang!" - med henvisning til at denne forening havde mistet adskillige medlemmer på grund af en diskussion om (u)passende opførsel for muslimske kvinder, efter forkvinden havde lagt hus til et møde i december, hvor hendes hjem (for børnenes skyld, som hun forklarede) havde været pyntet til jul.

En anden forklarede at ligestilling var et kontroversielt emne, og at der ikke var nogen grund til at gøre folk kede af det og skabe konflikter i deres fritid; det frivillige arbejde $\mathrm{i}$ foreningen kostede rigeligt energi i forvejen. Derfor var hendes personlige strategi at tale med de kvinder der måtte føle et behov derfor under fire øjne. En anden udtalte at "Hele tiden, når vi diskuterer med vores mænd, så diskuterer vi det meget stille. Ikke noget med stress". For nogle af hendes medlemmer kunne deltagelse i foreningens aktiviteter bero på forhandlinger med deres ægtefæller. På den anden side organiserede de ofte underholdning for børnene, hvilket bevirkede at mændene gav efter, for at få ro i hjemmet og slippe for børnenes plageri.

Én forklarede, at kvinderne i hendes forening som regel brugte hinanden til at diskutere deres problemer, "men lige præcis ligestilling..." - og hun afsluttede aldrig sæt- ningen, men tilføjede at "Vi som muslimer, vi snakker ikke så meget om ligestilling [...]. Vi snakker om respekt". Disse svar er forenelige med billedet af "den undertrykte indvandrerkvinde" (Andreassen 2007), og enkelte forbinder direkte fraværet af diskussionen om ligestilling med islam som religion. Den dominerende diskurs tilbyder foruddefinerede subjektpositioner som både jeg selv som interviewer og mine respondenter i varierende grad kan identificeres med. Fx 'passer' jeg til min rolle, når jeg helt undlader at spørge om ligestilling, fordi jeg tror det er et emne som er svært for respondenterne at tale om, ligesom de seks kvinder, der gav udtryk for at kønsligestilling var et svært emne at diskutere, i nogen grad 'passer' ind i de dominerende forestillinger.

Udover de seks personer der så ligestilling som et upassende emne i deres foreningskontekst, var der to der helt undlod at svare på spørgsmålet. Begge drejede emnet ind på bredere fortolkninger af ordet 'ligestilling', og diskuterede demokrati og menneskerettigheder, uden at berøre kønsligestilling. Dette var næppe fordi de anså ligestilling for et kontroversielt emne (de øvrige dele af disse interviews er ikke kendetegnet af tilbageholdenhed), men muligvis fordi de anså kønsligestilling for sekundært til andre ligestillingsproblematikker. Denne fortolkning understøttes af Seidenfaden et al., der påpeger at "Blandt de etniske minoriteter selv forstås ligestilling oftere som etnisk ligestilling end som kønsligestilling" (2011: 58).

Desuden var der tre respondenter der direkte påpegede, at køn kun var én blandt flere relevante kategorier. Én udtalte eksplicit at hun ville prioritere køn: “jeg går ind for ligestilling inden for alle områder. [...] Men det, der interesserer mig allermest, det er ligestilling mellem kønnene". Derimod anså en anden etnisk ligestilling for at være vigtigere: "i Danmark der har du de samme muligheder som drenge og mænd. [...] jeg tror generelt har indvandrere andre proble- 
mer, så det er ikke lige det, der er i fokus".

Disse henvisninger til andre problemer bærer vidnesbyrd om den kritik der bl.a. refereres i Borchorst om at "den skandinaviske ligestillingsfortælling frem for alt har fokuseret på forskelle mellem mænd og kvinder, og den har været etnocentrisk og har usynliggjort uligheder og magtrelationer mellem kvinder" (2009: 181). Både de respondenter der forholder sig tavse om kønsligestilling, men aktivt til andre former for ligestilling, og de der aktivt rangordner det i forhold til andre problemer, representerer derved en moddiskurs til den dominerende forestilling om Danmark som ligestillet, fordi de eksplicit eller implicit påpeger at det ikke er nok at fokusere på forskelle mellem mænd og kvinder.

Betragtes datamaterialet i sin helhed, er det dog en anden moddiskurs der dominerer, nemlig de 11 svar der på én gang reproducerer diskursen om 'dansk' ligestilling, men også stiller spørgsmålstegn ved om målet er nået. Det er særligt her, at materialet åbner op for den "dialog, der går flere veje, og som kan rumme forskellige mål og forudsætninger" som Khankan efterlyser (2006: 154). Nogle af kvinderne støttede umiddelbart den dominerende diskurs om Danmark som et land med ligestilling. For eksempel sagde en kvinde at "In Denmark, equality is very good. I don't have any objections to the way they are treating the women, how they are doing it, and have their equality and the job and everything. I think it is good, it is very nice".11 Dog kombinerede langt de fleste sådanne typer af udsagn med mere kritiske kommentarer. Således tilføjede samme respondent:

"But when the women have got equality with the men, they make too much of themselves. They shouldn't do that. [...] in Denmark equality - they make too much of it the women. Because they say "I bestemme den her ting". Det er ikke så godt. When you want to bestemme the things, det er ikke så godt. It is destroying the whole family, the children, everything. So the bestemming should be equal".

Denne respondent anerkender og bifalder ligestilling som værdi i Danmark, men i modsætning til diskursen om at Danmark har noget at lære andre $\mathrm{i}$ forhold til at praktisere ligestilling, anfægter hun tværtimod det hun opfatter som en konfronterende stil blandt danske kvinder, der slår på ligestillingens vigtighed. Til forskel herfor, omtalte hun en anden kulturel praksis, hvor direkte konfrontation bliver undgået, men kvinder ikke desto mindre har stor reel selvbestemmelse.

Ganske mange af de interviewede kvinder brugte netop interviewene som en anledning til at fremføre argumenter om at ligestilling kan have forskellige udtryk, og derved sætte spørgsmålstegn ved den dominerende tilgang. Diskursens dominans kan blandt andet spores i de mange omhyggeligt artikulerede forklaringer om at islam ikke som religion er undertrykkende overfor kvinder. Bl.a. var der en muslimsk kvinde12 der svarede at "mine værdier siger også at folk har lige værdi”, og hun følte at danskere har fordomme om at den muslimske religion undertrykker kvinderne, hvilket ifølge hende ikke var sandt. Hun kunne slet ikke forstå de muslimske mænd der ikke behandler kvinderne godt, fordi det ifølge hende var imod hvad Koranen siger, nemlig "Kvinden skal betragtes som et ligeværdigt menneske". Derfor arbejdede hun for at forbedre kvinders uddannelsesniveau og selv lade dem lase Koranen og diskutere teksten med hinanden. Dermed forfulgte hun den strategi som Badran (1994) omtaler som "Islamic modernism".

Atter andre respondenter lagde dog stærk og tydelig afstand til hvad de opfattede som kønsdiskrimination i islams navn. Samtidig understregede de også, at det at leve $\mathrm{i}$ et overvejende muslimsk land langt fra er det samme som at gå ind for kvinders undertrykkelse. 
"Selvom du tager bare ét land, bare blandt iranere, et enkelt land, så er der kolossal forskel mellem den kulturelle, uddannelsesmæssige og sociale baggrund. Folk som har boet i Teheran og er universitetsuddannede og har været aktive og - altså, faktisk mange mænd de $e r$ feminister [...] Du har også nogle mænd, som er meget mere mandschauvinistiske, og som er bundet til deres kulturer og gamle traditioner".

Mange af de svar der understregede nationale og regionale forskelligheder indenfor lande hvor islam er en dominerende religion, eller påpegede forskellige fortolkninger af Koranen, kom fra kvinder der var ankommet til Danmark som politiske flygtninge. Mange af disse personer forbandt deres livshistorier med deres egen eller deres forældres engagement i politiske partier (ofte på venstrefløjen) og deltagelse i forskellige forbudte aktiviteter i deres oprindelseslande (såsom udbredelse af læsefærdigheder blandt kvinder eller information om prævention). Alt dette gav input til nogle overordentlig spændende samtaler, ikke mindst fordi det ofte satte det dominerende billede af den undertrykte indvandrerkvinde i stærk relief, og samtidig bidrog til nogle kritiske kommentarer vedrørende den dominerende danske diskurs om ligestilling.

"Men jeg kan godt fortælle dig, da jeg kom til Danmark [...] så mødte jeg nogle danske kvinder, som faktisk kxmpede for ligestilling. På det tidspunkt - ligestilling - tænkte jeg, det er umuligt tænkte jeg, hvordan kan det lade sig gøre at kvinder og mænd kan være ligestillet? [...] Jeg er ikke dansk kvinde, men altså jeg kan se, når danske kvinder kommer hjem, så er det mest dem, der skal have omsorg til familien, det er mest dem, der skal tage sig af hjemlige, hvad hedder det, hjemmearbejde, er det ikke rigtigt? [...] ligestillet, det er i Iran, der er jo meget, meget, meget langt fra. Men i Danmark måske, det er lidt tættere. Men stadigvæk, der er ingen ligestilling. Det er min opfattelse i hvert fald".
Hun fortsatte med observationer om det høje antal kvinder i dansk politik, men stadig meget lave antal på direktionsgangene. En observation hun kxdede sammen med sine personlige erfaringer om at møde næsten udelukkende kvinder i forskellige omsorgsfunktioner i det offentlige, bl.a. på sygehuse, skoler og i daginstitutioner. Andre tilsluttede sig synspunktet om at danske kvinder ( $\mathrm{i}$ betydningen alle kvinder bosat $\mathrm{i}$ Danmark) stadig havde et stykke vej at gå. For eksempel havde én meldt sig ind i et politisk parti for at forsøge at gøre noget ved sagen, og observerede at

“i år er det hundrede år siden, kvinder fik stemmeret i Danmark - når man tænker på, hvor meget, man har opnået i de første tres år af de hundrede år, så er det rigtig meget. $\mathrm{Og}$ så er det som om, vi er gået i stå, og specielt inden for de sidste 15-20 år. Kvinderne tager høje uddannelser, men hvorfor er de ikke i de ledende stillinger?"

De fleste respondenter anerkendte derved vigtigheden af den formelle ligestilling blandt kønnene i Danmark, men der var bestemt ikke tale om en ukritisk tilslutning til diskursen om ligestilling som et dansk varemærke. Det interviewudsagn der måske mest sigende opsummerer den tilgang, var følgende udtalelse: "Jamen ligestilling, jeg synes det er så dejligt et ord, som jeg bare hører".

\section{KONKLUSION: EN POLYMORF DEBAT}

Langt de fleste respondenter genkendte og applauderede den juridiske mulighedslighed mellem kønnene i Danmark - særligt den lige adgang til uddannelse, rettigheder i forbindelse med skilsmisse og ret til politisk deltagelse blev fremhævet. Diskursen om Danmark som et land med ligestilling var der derimod begrænset tilslutning til. Flere af kvinderne havde stærke personlige erfaringer med hvad manglende mulighedslighed mellem kønnene betyder. Men selv 
om mange understregede at de værdsatte den juridiske mulighedslighed i Danmark, påpegede flere at der i Danmark fortsat er større sandsynlighed for at møde kvinder i rollen som skolelærer eller børnehavepædagog end på direktionsgangen, og dermed at der ikke er opnået udfaldslighed. Dette udgør én form for moddiskurs til den monopoliserede ligestillingsdebat.

Samtidig understreger interviewene, at disse kvinder ikke entydigt ser sig selv som 'problembærerne' i forhold til at opnå ligestilling, og at mange udfordrer diskursen om indvandrerkvinder som undertrykte. Udsagnene demonstrerer, at dette kan gøres både ved at lægge afstand til islam og ved at bekende sig til islam. Der er dog tydeligvis også flere blandt de interviewede der oplever såvel manglende etnisk ligestilling som manglende kønsligestilling som et problem i deres hverdag, og fx må forhandle med deres mænd for at have et liv udenfor hjemmet. Fokus på den manglende etniske ligestilling udgør en anden form for moddiskurs i debatten.

Alt $\mathrm{i}$ alt læser jeg disse udsagn om ligestilling som et interessant og vigtigt bidrag til at kunne åbne op for en polymorf ligestillingsdebat i Danmark, der levner plads til forskelligartede moddiskurser. Ovenstående analyse bekræfter på den ene side dominansen af diskursen om Danmark som et ligestillet land, men demonstrerer samtidig at forskellige positioneringer som majoritets- eller minoritetskvinde, muslimsk eller ej, på ingen måde er en god indikator for hvilken ligestillingsopfattelse der artikuleres. Dermed bliver debatten et mål i sig selv, fordi man i det øjeblik man indtræder i en afmonopoliseret dialog med de personer der som udgangspunkt var markeret som 'de andre' netop får lejlighed til at udsætte sig selv for en empirisk demonstration af hvilke forskellige forståelseshorisonter der cirkulerer. Artiklen her bliver selvfølgelig sub-optimal, fordi der er tale om min formidling af en tidligere dialog, hvori jeg på flere måder sad i den mest magtfulde posi- tion som interviewer. Det er den næstbedste løsning. Den bedste er at finde nogen at debattere med.

\section{Noter}

1. Af hensyn til lasevenligheden bruger jeg 'minoritet', 'majoritet' og 'etnicitet' uden citationstegn, skønt jeg er enig med Gunaratnam (2003: 19) i at de udgør farlige kategoriseringer, og at der snarere er tale om processer hvorved visse grupper bliver 'minoritized' eller 'ethnicized'.

2. Tak til Signe Kjær Jørgensen for kommentarer på en tidligere version af denne artikel.

3. Se fx Christensen 2009 for en diskussion af danske majoritetskvinders syn på feminisme og ligestilling.

4. Danmark rangerer som hhv. nr. 11 (kvinder i bestyrelser) og 19 (løngab) ud af 41 lande i disse tabeller, der findes i et interaktivt excel ark der kan hentes via http://www.oecd.org/site/elsgender/ 5 . For at opnå tilstrækkelige data, blev dette omgået i Aalborg, hvor jeg i højere grad måtte stole på feltets egne oplysninger om, hvilke foreninger der havde mange aktive kvindelige medlemmer.

6. Om kvinderne faktisk identificerede sig som muslimer, blev diskuteret i interviewet.

7. Jævnfør Serviceloven af hhv. 2006 og 1997.

8. Enkelte var gruppeinterviews, derfor det højere antal respondenter. Kvinderne kom fra følgende foreninger:

Fra Aarhus: Kvindehuset i Aarhus, Somali Women s Organisation Denmark, Den Aktive Kvindeforening, PigeLiv, Projekt Hawa, Livsværkstederne, Interkulturel Kvindeforening \& International Kvindeforening.

Fra København: Hennah.dk, Multikulturel Kvindeklub Amager, En Ny Vej for Kvinder til Arbejdsmarkedet, Dialog 2, Mødestedet i Tingbjerg, Kurdisk Kvindeforening, Dansk Palæstinensisk Kvindeforening, Kringlebakken, Iransk Kvindeforening, Afghansk Kvindeforening, Foreningen af Kvinder til Integration (FAKTI) \& Verdens Kvinder. Fra Aalborg: Nordjyllands Internationale Klub (NIK), Kvinders Vækst, Somalisk Kvindeforening, Irakisk Kvindeforening, Dansk Kurdisk Kultur Forening \& Iransk Kulturforening.

9. Kategoriseringerne er baseret på kvindernes egne angivelser. Forkvinderne for de tre kurdiske foreninger omtalte sig selv som hhv. irakisk kurdisk eller tyrkisk kurdisk.

10. For uddybende diskussion, se kennedy-macfoy og Pristed Nielsen (2012). 
11. Efter respondentens eget ønske, var dette interview på engelsk. Alle andre foregik på dansk. Interviewene blev i videst muligt omfang transskriberet i overensstemmelse med respondentens idiomatiske udtryk.

12. Hun erklærede sig som troende muslim i interviewet.

\section{LITTERATUR}

- Ahmed, Leila (1992): Women and Gender in Islam. Yale University Press, New Haven.

- Ali, Shaheen Sardar (2000): Gender and Human Rights in Islam and International Law: Equal Before Allah, Unequal Before Man? Kluwer Law International, Haag.

- Andreassen, Rikke (2007): Der er et yndigt land. Medier, minoriteter og danskhed. Tiderne Skifter, København.

- Andreassen, Rikke \& Siim, Birte (2007): Country Report Denmark. Rapport fra VEIL projektet. Lokaliseret d. 27/4 2012 på http://vbn.aau.dk/files/13647235/Country_Report_Denmark_VEIL - Alcoff, Linda Martin (1991-92): The Problem of Speaking for Others. Lokaliseret d. 25/1 2012 på http://www.alcoff.com/content/speaothers.html - Bacchi, Carol Lee (2009): Analysing Policy: What's the problem represented to be? Pearson Education, French Forest, New South Wales.

- Badran, Margot (1994): Feminists, Islam and Nation: Gender and the Making of Modern Egypt. Princeton University Press, New Jersey.

Borchorst, Anette (2009): Køn, lighed og forskellighed. Wollstonecrafts dilemma i dansk kontekst, i: Holtug, Nils og Lippert-Rasmussen, Kasper (red.) (2009): Lige muligheder for alle - Social arv, kultur og retferdighed. Nyt fra Samfundsvidenskaberne, Frederiksberg.

- Christensen, Ann-Dorte (2009): Young women s attitudes towards feminism and gender equality, i: Kari Melby, Anna-Birte Ravn og Christina Carlsson Wetterberg (red.), Gender Equality and Welfare Politics in Scandinavia. The limits of political ambition? The Policy Press, Bristol.

- Gullestad, Marianne (2002): Invisible Fences: Egalitarianism, Nationalism and Racism, i: Royal Anthropological Institute 8: 45-63. . Gunaratnam, Yasmin (2003): Researching 'Race' and Ethnicity. Methods, Knowledge and Power. Sage Publications, London.

- Holtug, Nils og Lippert-Rasmussen, Kasper (red.) (2009): Lige muligheder for alle - Social arv, kultur og retfardighed. Nyt fra Samfundsvidenskaberne, Frederiksberg.

- Jørgensen, Signe Kjær (2012): Why wear a headscarf in parliament? Danish secularist, nationalist and feminist ideas about Muslims, i: Christopher Flood, Stephen Hutchings, Galina Miazhevich and Henri Nickels (red.): Political and Cultural Representations of Muslims. Islam in the plural. Brill, Leiden.

- kennedy-macfoy, madeleine og Pristed Nielsen, Helene (2012): We need to talk about what race feels like. Using feminist memory work to analyse the production of race and ethnicity in research encounters. Qualitative Studies. 3 (2): 133-149. - Khankan, Sherin (2006): Islam og Forsoning - en offentlig sag. Lindhardt og Ringhof, København. - OECD (2011): The Gender Data Browser. Lokaliseret d. 23/10 2012 på http://www.oecd.org/site/elsgender/

- Rolandsen Agustín, Lise (2009): Eurosphere Working Paper Series, No. 22. Lokaliseret d. 27/9 2009 på: http://www.eurosphere.uib.no/knowledge/wpsdocs/Eurosphere_Working_Paper_22_Agustin.pdf

Seidenfaden, Line; Winkel Madsen, Mathilde; Bech Christensen, Signe Emilie; Rahbæk Asserhøj, Helle (2011): Konsligestilling blandt etniske minoriteter $i$ Danmark. Als Research, København. - Spivak, Gayatri C. (1988): Can the Subaltern Speak?, i: Gary Nelson \& Lawrence Grossberg (red.): Marxism and the Interpretation of Culture. Macmillan Education, Basingstoke.

. Udlændingestyrelsen (2006): Erklaring om integration og aktivt medborgerskab $i$ det danske samfund. Lokaliseret d. 15/8 2012 på

http://www.nyidanmark.dk/da$\mathrm{dk} /$ Blanketter/SearchForms.htm?SearchType=for ms\&Subject=Integration\%20af\%20nyankomne\&Su bSubject=Aktivt $\% 20$ medborgerskab\&PerformSearch=True

-World Economic Forum (2011): Global Gender Gap Report. Lokaliseret d. 12/4 2012 på http://www3.weforum.org/docs/WEF_GenderGap_Report_2011.pdf

\section{SUMMARY}

According to the latest Global Gender Gap Report (WEF 2011), Denmark ranks as number 7 out of 135 countries, meaning that the country is among the most successful in the world when it comes to gender equality. 
Much research also points to how this is a dominant understanding within Danish political and media discourse, which in contrast tend to cast immigrant women as gender unequal. The article asks: how might immigrant women living in Denmark challenge the dominant understandings of gender (in)equality? Interviews with 34 leaders of various immigrant women's organisations demonstrate that the dominant discourse tends to predefine majoritized as well as minoritized positions, which some of the women actively challenge while others do not. Adding their voices to the debate accentuates the predominance of the discourse, as well as the difference between equality of opportunity and equality of outcome.

Helene Pristed Nielsen, lektor EDGE - Centre for Equality, Diversity, Gender Aalborg Universitet 